\title{
Özofagus kanserinin epidemiyolojisi
}

\author{
Epidemiology of esophagus cancer
}

\author{
Ayşen Taslak Şengül \\ Ondokuz Mayıs Üniversitesi, Tıp Fakültesi, Gögüü Cerrahisi Anabilim Dalı, Samsun, Türkiye
}

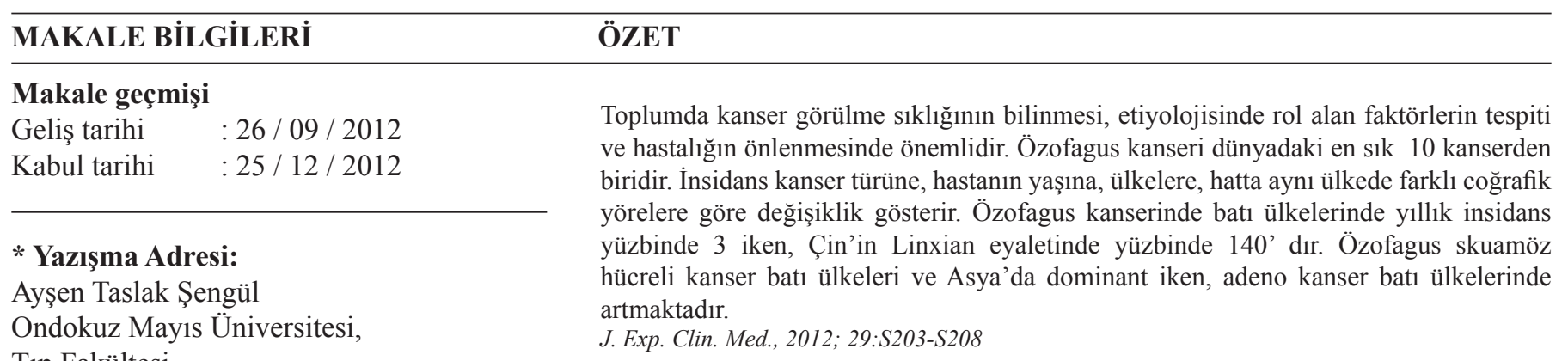

Tıp Fakültesi,

Göğüs Cerrahisi Anabilim Dalı,

Samsun

e-posta: ataslak@omu.edu.tr

\begin{abstract}
Knowing the incidence of cancer in a society plays a significant role in detecting the factors involving its etiology and prevention of the disease. Esophageal cancer is among the most common 10 cancers. The incidence of esophageal cancer changes in terms of histological type of cancer, patient's age, country, and even in different geographical regions of the same country. While the incidence in Western countries is 3 in 100.000, it is 140 in China. Although esophageal squamous cell carcinoma is dominant in Western countries and Asia, frequency of adenocarcinoma is increasing in Western countries. J. Exp. Clin. Med., 2012; 29: S203-S208
\end{abstract}

\author{
Anahtar Kelimeler: \\ Özofagus \\ Kanser \\ Epidemiyoloji \\ İnsidans \\ Prevalans
}

\author{
Keywords: \\ Esophagus \\ Cancer \\ Epidemiology \\ Incidence \\ Prevalence
}

\section{Giriş}

Toplumda kanser görülme sıklığının bilinmesi, rol alan faktörlerin tespiti ve hastalığın önlenmesinde önemlidir. Ayrıca hastalığın erken teşhisi ve tedavinin etkinliğine de katkı sağlar. Kanser insidansı, kanser türüne, hastanın yaşına, cinsiyetine, coğrafik bölgeye göre değişiklik gösterir. Dünyada kanser insidansı yüzbinde 85-350 arasında değişir (Parkin ve ark., 2005). Dünyada 2002 yılında 10,9 milyon yeni kanser vakasının görüldüğü, 6,7 milyon kişinin kanser nedeniyle öldüğü ve 24,6 milyon kişinin kanserli olarak yaşama devam ettiği bildirilmiştir (Parkin ve ark., 2005).

Kanser ülkemizde Sağlık Bakanlığı tarafından 1983'de, bildirimi zorunlu hastalıklar listesine alınmıştır. Ancak beklenen verilerin sadece dörtte birinin elde edilmesi nedeniyle
1992 y1lından itibaren 10 merkezden aktif veri toplama sistemine geçilmiştir. Sağlık Bakanlığı kanser kayıt merkezinin verilerine göre Türkiye'de 2006 yılında kanser insidansı yaklaşık 200/100000, gelişmiş ülkelerde bu oran 400/100000'dür (Eser ve ark., 2006). Verilerin yeterli toplanamamasına rağmen elde edilen bu oran ülkemizde kanserin önemli bir sağlık sorunu olduğunun göstergesidir.

Sağlık Bakanlığı tarafından 2006 yılı kanser istatistiklerinde Türkiye'de 8 ilden veriler bildirilmiştir. En fazla hasta İzmir, Ankara, Antalya ve Samsun'dan olmak üzere Bursa, Edirne, Trabzon ve Erzurum illeri değerlendirilmiştir. Bu verilerde toplam 69147 vaka toplanmıştır. Erkeklerde kanser insidans1 245,60/100000 ve kadınlarda 164,40/100000 olarak bulunmuştur. Bu verilerde özofagus kanseri Türkiye'de en 
sık tespit edilen 10 kanser arasında yer almamıştır. Sadece Erzurum ili verilerinde özofagus kanseri 5. sırada 5,44/100000 insidansı ile bildirilmiştir. Özofagus kanseri Erzurum'da kadınlarda 6,53/100000 insidansla 3. sirada, erkeklerde 4,43/100000 insidansla 6. sırada görülmektedir (Pera ve ark., 2005; Karaca ve ark., 2011).

Ülkemizde özofagus kanseri sıklığı, bölgesel yapılan epidemiyolojik çalışmalarla belirlenmiştir. Van ili ve çevresinde yapılan kanser insidansı çalışmalarında özofagus kanserini kadınlarda Uğraş ve ark. (1996) \% 15,7, Kösem ve ark. (2001) \% 17,9, Bayram ve ark. (2005) \% 16,9 ile ilk sirada, Alıcı ve ark. (2006) \% 19,2 ile ikinci sırada tespit etmişlerdir. Erkeklerde ise özofagus kanseri Alıcı ve ark. (2006) \% 13,2 ile 2. sırada, Bayram ve ark. (2005) 4. sırada, Uğraş ve ark. (1996) ve Kösem ve ark. (2001) 5. sırada tespit etmişlerdir. Bozkurt ve ark. (2011) tarafından yayınlanan Şırnak ve çevresini değerlendiren çalışmada kadın \% 2 ve erkek \% 4,83 ile her iki cinste 5 . sırada özofagus kanseri görülmüştür. Karaca ve ark. (2010) yayınladıkları çalışmalarında Kayseri ili ve çevresinde özofagus kanseri en sık görülen 5 kanser arasında yer almamıştır.

Dünyada ve ülkemizde özofagus kanseri riski coğrafik bölgeler arasında değişiklik gösterir. Ayrıca histolojik subtiplerin görülme sıklığı da ülkeler arasında farklıdır (Oze ve ark., 2011). Özofagus skuamöz hücreli kanser batı ülkeleri ve Asyada dominant iken, son elli yıldır adeno kanser batı ülkelerinde özellikle beyaz ırkta hızlıca artış göstermektedir. Batı ülkelerinde adeno kanserdeki hızlı artışın majör belirleyicisinin obezite ve buna bağlı gastroözofageal reflu (GÖR) olduğuna inanılır. Asya'da böyle bir artış tespit edilmemiştir (Hongo ve ark., 2009).

Özofagus kanserleri insidansı ülkelere, hatta aynı ülkede farklı coğrafik yörelere göre değişiklik gösterir. Çin'de ülke genelinde özofagus kanserinin görülme insidansı yüksektir ve bazı eyaletlerde bu oran 3-4 kat daha fazladır. Özellikle yüksek riskli bölgelerde her 3-5 kişiden biri özofagus kanseri nedeni ile ölmektedir. Yüksek riskli Çin ile düşük riskli batı Afrika arasında görülme sıklığındaki fark 300 kata çıkabilmektedir. Çin'de ülkenin tamamı özellikle Linxien eyaleti, Güney Afrika'da Transkei, İran'da Gonbat, Golestan ve Hazar Denizi kıyıları, Japonya, Hindistan'da Bombay, Kazakistan, Türkmenistan, Kore, Singapur, Porto Riko, Sri Lanka ve Rodezya insidansın belirgin şekilde yüksek olduğu bölgelerdir (Ökten I., 2003).

\section{Kanser tipine göre insidansın zaman içinde değișimi}

Özofagus adeno kanseri batı ülkelerinde hızlı artış göstermiştir (Pera ve ark., 1993; Bollschweiler ve ark., 2001). Amerika'da 1970'lerde beyaz erkekler arasında insidans 0,50,9/100000 iken son 20 yılda 3,2-4,0/100000'nin üzerine çıkmıştır (Blot ve ark., 1991; Kubo ve Corley, 2004). Benzer artışın İngiltere, Avustralya, Kuzey Avrupa ve İzlanda'da beyaz ırkta görüldüğü bildirilmiştir. Bu ülkelerde skuamöz/adeno kanser oranı beyaz erkeklerde 1975' de 4,7:1 iken 1995 y1lında 2,1:2'e düşmüştür. (Daly ve ark., 1996; Devesa ve ark., 1998). 1996-98'de bu oranın tersine dönerek 0,43:1 olduğu bildirilmiştir (Kubo ve Corley, 2004). Başka bir yayında yıllık adeno kanser insidansını 1980'lerin sonunda squamöz hücreli kanseri geçtiği bildirilmiştir (Pickens ve Orringer, 2003). $\mathrm{Bu}$ artışın reflu özöfajit prevelansında artışla korele olduğu bulunmuştur. Muhtemelen yağ ve total enerji alımında artı- şın obezite ile sonuçlandığı ve bunun da Helicobacter pylori (HP)'de azalmaya neden olduğu düşünülmüştür. Ayrıca bu hassasiyetin sadece beyaz erkeklerde görüldüğü bildirilmiştir. Beyaz erkekler arasında adeno kanserdeki artışla, epidermoid kanser ile insidansın ters döndüğü sunulmuştur. Siyah Amerikalılar arasında epidermoid kanser azalması yanında adeno kanser insidansının çok az derecede arttığı yayınlanmıştır. Dünyanın geri kalanında epidermoid kanser insidansı göreceli olarak stabil kalmıştır veya çok az azalmıştır. Ayrıca adeno kanser insidansında Asya ülkelerinde ve Amerika'da yerleşmiş Asyalılarda değişiklik görülmemiştir (Hongo ve Shoji, 2003; Pickens ve Orringer, 2003; Son ve ark., 2001).

\section{Kanser tipine göre görülme sıklı̆̆ı}

Özofagus kanser prevalansinda, hücre tipine göre, batı ve asya ülkeleri arasında belirgin fark vardır. Adeno kanser, İngiltere'de 4,0-8,7/100000, Avustralya'da 4,8/100000 insidansla daha s1k olarak görülür (Bollschweiler ve ark., 2001). Yang ve Davis (1988)'e göre birleşik devletlerde skuamöz kanser insidansı y1llık 2,6/100000'dır. İrlanda ve İngiltere kendi içinde değerlendirildiğinde; adeno kanser insidansı İrlanda ve İskoçya'da iki katdır. Avrupa ülkeleri değerlendirildiğinde; Güney Avrupa'da (İspanya, Fransa, İtalya) kümülatif adeno kanser oranı yüksektir. Bunu Kuzey Avrupa (Danimarka, Norveç, İsveç, Finlandiya) ve Batı Avrupa (Hollanda, Almanya, İsviçre) takip eder. Avrupa ülkeleri içinde adeno kanserin en düşük insidansı Doğu Avrupa ülkelerindedir (Corley ve Buffer, 2001).

Asya ülkelerinde epidermoid kanser dominant tiptir. Özellikle Çin, Tayvan ve Singapur'da yaşayan Çinlilerde, Kore ve Japonya'da epidermoid kanser sik görülür. Asya ülkelerinde adeno kanser insidansı oldukça düşüktür. Özellikle Doğu Asya ülkelerinde epidermoid kanser insidansı adeno kanser insidansından daha yüksektir. 1970-1990 arası özofagus maligniteleri arasında adeno kanser insidansı Kore, Tayvan ve Japonya' da \% 1-4'dür. Adeno kanser insidansı Güney Asya ülkelerinde (veya Hindistan) doğu ve güneydoğu Asya ülkelerinden daha yüksektir. Yine de beyaz ırkın çok olduğu ülkelerden ve Avrupa'dan daha düşüktür (Corley ve Buffler, 2001).

\section{Sosyoekonomik faktörlerin etkisi}

Sosyoekonomik faktörlerden bazılarının özofagus kanserinde muhtemel risk faktörü olabileceği bildirilmiştir. Kötü sosyoekonomik düzey epidermoid kansere, zengin sosyoekonomik düzey adeno kansere neden olabilir. Özellikle Barret özofagus ve adeno kanser sosyoekonomik durum gelişimiyle paraleldir. Özofagus kanserinin epidemiyolojisinde coğrafik farklar da sosyoekonomik düzeyle ilişkilidir. Sosyoekonomik düzeyde düzelme $H$. pylori enfeksiyon prevalansını azaltarak gastrik mukoza atrofisinde azalmaya yol açar (Asaka ve ark., 1992; Hongo ve Shoji, 2003). Aşırı nutrisyonal destek obeziteye neden olur. Bu değişiklikler gastroözofageal reflüde (GÖR) artışa ve Barret özofagus ve adeno kanser prevelansında artışa neden olabilir. Kısaca adeno kanser insidansı yüksek olan bölgelerde (İngiltere, Amerika, Avustralya gibi) obezite prevalansı (beden kitle indeksi $\geq 30 \mathrm{~kg} / \mathrm{m}^{2}$ ) ve kişi başına düşen günlük enerji tüketimi diğerlerine göre daha yüksektir (Hongo ve Shoji, 2003).

Özofagus kanseri epidemiyolojisi için GÖR ve GÖR ile ilgili hastalıklar (Barret özofagus gibi) Pasifik Asya bölgesin- 
de sosyoekonomik duruma göre değişir. Gerçek etnik farklar aynı bölgede yaşayan farklı etnik grupların değerlendirilmesi ile açığa çıkar. Singapur'da yapılan çalışmada; adeno kanserin baskın olduğu Güney Asya ve epidermoid kanserin dominant olduğu Doğu Asya insanlarının, coğrafik hassasiyeti aynı bölgede yaşayan 3 etnik grup arasında gözlenmiştir (Çinli, Hintli, Malezyalı) (Fernandes ve ark., 2006). Ayrıca adeno kanser için çevresel faktörlerin yanında, etnik veya genetik faktörlerin de adeno ve epidermoid özofagus kanserinin epidemiyolojisinde oldukça güçlü olduğu bulunmuştur (Hongo ve ark. 2009).

\section{Etiyoloji}

Hongo ve ark. (2009) çalışmalarında özofagus kanserinde her iki histolojik tip için risk faktörlerini değerlendirdiler (Tablo 1).

\section{Tablo 1. Özofagus kanserinde risk faktörleri}

\begin{tabular}{lcc} 
Risk faktörleri & Epidermoid kanser & Adeno kanser \\
\hline Sigara içiciliği & +++ & ++ \\
Aşırı alkol tüketimi & ++ & ++ \\
Baret özofagus & - & +++ \\
GÖR & - & +++ \\
Obezite & - & ++ \\
Aşırı enerji tüketimi & - & + \\
Aşırı yağ tüketimi & - & ++ \\
Yoksulluk & ++ & - \\
Düşük eğitim düzeyi & + & - \\
Sıcak içecek tüketimi & + & - \\
H.pylori enfeksiyonu & Koruyucu etki & Koruyucu etki \\
\hline
\end{tabular}

+++; Çok güçlü etki, ++; orta derecede güçlü etki, +; az etki, -; etkisiz

Özofagus kanserinin etiyolojisinde rol oynayan faktörler 5 başlik altında incelenebilir.

1.Sigara ve alkol

2.Beslenme ile ilgili faktörler

3. Çevresel faktörler

4.Genetik faktörler

5.Predispozan hastalıklar

Çoğu risk faktörü tek hücre tipine etkiliyken sigara içiciliği ve aşırı alkol tüketiminin her iki tip için de risk faktörü olduğu görülüştür. Adeno kanseri etkileyen risk faktörleri ekonomik olarak gelişmiş ülkelerde görülürken, epidermoid kanserlerin gelişmekte olan ülkelerde yaygın olduğu bulunmuştur. Helicobacter pylori enfeksiyonunun özellikle adeno kanserde olmak üzere her iki tipte koruyucu etkisi tespit edildi. Ancak yine de özofagus kanseri etiyolojisinde sosyoekonomik durumun ve etnik kökenin etkisi açık değildir. Gelecekte daha kapsamlı çalışmalarla veriler tekrar analiz edilmelidir.

\section{Sigara ve alkol}

Sigara ve alkol özofagus kanserlerinde önemli risk faktörleridir. Coğrafik bölgeye göre etkisi değişebilir. Oze ve ark. (2012) çalışmalarında Japon populasyonunda özofagus kanseri riskinde sigaranın güçlü etkisi olduğunu bulmuşlardır. Alkol ve tütün kullanımı Amerika'da, Avrupa'da ve özellikle Fransa'da da en önemli etiyolojik faktördür (Lewin ve ark.,1992). Alkolün etkisi tek başına oldukça az olup, sigara ile birlikteliğinde özofagus kanseri riski doz ve süreye bağlı olarak çok yükselmektedir. Günde 15 taneden daha az sigara içenlerde rölatif risk 2 iken, günde 25 taneden fazla içenlerde 6 olarak bulunmuştur. Sigara ile alkol birlikte alındığında, alkol almayan sigara içenlere göre skuamöz hücreli karsinoma riski 10-25 kat artmaktadır. Sigarayı bırakmak ile skuamöz hücreli karsinoma riskinde daha öncesine oranla \% 40 azalma görülmektedir (Wu ve ark., 2001; Bosetti ve ark., 2006).

Alkol kullanımı bırakıldıktan sonra 10 yıl içinde kanser riskinin, içmeyenlerdeki üst sınıra düştügü, sigara tüketiminin kesilmesini takiben 5 y1l içinde ise riskin \% 50 azaldığ yapılan çalışmalarda gösterilmiştir (Başoğlu, 2002; Ökten ve Güngör, 2003).

\section{Beslenme}

Taze meyve ve sebzelerin yetersiz tüketimi, beta-karoten, $\mathrm{A}, \mathrm{B}, \mathrm{C}$ ve $\mathrm{E}$ vitamini eksikliği, folik asit, riboflavin, eser mineral ve metallerden magnezyum, çinko ve selenyumun yetersiz alımı, diyette nitrozamin fazlalı̆̆ 1 etiyolojide rol oynayan faktörler arasındadır. Yağ, kolesterol ve hayvansal proteinlerin fazla miktarda tüketimi ve lifferden fakir diyetin adenokarsinom gelişme riskinde artış ile ilişkili olabileceği belirtilmektedir (Blot ve McLaughlin, 1999; Bosetti ve ark., 2006).

C vitamini ve beta-karotenden zengin olan diyetler kanser insidansında azalmaya neden olurlar. Çinko, selenyum ve molibden gibi bazı eser elementlerin yetersiz alınmasının yanında pirinç, buğday ve mısırdan zengin, taze meyve ve sebzeden fakir diyet ile beslenme, özofagus kanseri için önemli risk faktörleri oluşturmaktadır (Başoğlu, 2002). Sigara, alkol kullanımı ve taze sebze ve meyve ile yetersiz beslenme özofagus kanserli hastalarda \% 83 oranında tespit edilmiştir (Blot, 1994).

Tütsülenen ve tandırda pişirilen etli gidalardan yüksek oranda benzopiren açığa çıkar. Bu gibi kanserojen polisiklik hidrokarbonlar kanser gelişimine neden olur (Başoğlu 2002).

Sürekli aşırı sıcak gıdaların alınması riski belirgin ölçüde artırır (Garidou ve ark., 1996; Ghawamzadeh ve ark., 2001). Sigara ve çevresel faktörlerin etkisi ile özofagus epitelinde biriken kimyasal karsinojen maddeler, sıcak içecek ve alkol gibi irritanlarla epitele penetre olur ve bazal tabakaya kadar ulaşır. Ülkemizde Doğu Anadolu'da sigara ile beraber çok sıcak ve fazla miktarda çay içme alışkanlığı vardır. Ayrıca bölgenin iklim koşulları nedeniyle taze sebze ve meyve transportundaki güçlükler özofagus kanserinin sık görülmesinin nedenleri olarak düşünülebilir (Başoğlu, 2002).

\section{Genetik ve çevresel faktörler}

Özofagus skuamöz hücreli karsinomda en önemli onkogenin cyclin olduğu düşünülmektedir. Özofagus kanserli olguların \% 40-60'ında ve premalign lezyonların \% 30' unda cyclin D1 ekspresyonu artmıştır. Bunu yanında hst-1, c-myc, int-2, onkogenleri; transforme edici büyüme faktörü (TGF), trombositten üretilmiş büyüme faktörü (PDGF) ve epidermal büyüme faktörü (EGF) gibi büyüme faktörleri, displastik epitel ve tümör hücresinde belirgin olarak saptanmıştır. Özofagus kanseri gelişiminde elimine olduğu veya silindiği düşünülen tümör supressör genler p53 (375 aminoasitli bir fosfoprotein), Rb (retinoblastoma geni), APC (kolonun ailesel adenomatöz polip gelişimindeki gen) ve MCC (sporadik kolon kanseri gelişiminden sorumlu gen)'dir. Özofagus 
kanserlerinin \% 70'in de p53 mutasyonu vardır. Özofagus kanseri gelişimi için bu genlerin her iki kopyasının da elimine edilmiş veya kaybolmuş olması gereklidir (Moutesano ve ark., 1996; Başoğlu ve ark., 1998).

Çevresel faktörlerden özellikle, sulardaki karsinojen bileşiklerin etkisi üzerinde durulmaktadır. Petrol bölgelerinde suyun petrol ile kontaminasyonu, insidansin yüksek olduğu bazı bölgelerde suda nitrojen bileşiklerinin yüksekliği, bazı bölgelerde riboflavin eksikliğinin gösterilmesi çevresel faktörlerin etkisini desteklemektedir. Çevresel faktörler arasında asbest maruziyeti, radyasyon ve viral etkenler de sayllabilir (Blot, 1994; İkeda ve ark., 1999).

\section{Predispozan faktörler \\ Barret özofagus}

Barret özofagus, distal özofagusun normal skuamöz epitelinin intestinal kolumnar epitel ile metaplastik değişimidir (Spechler ve Goyal, 1996). GÖR'e sekonder gelişir. Barret özofagusun, reflu nedeniyle endoskopi yapılan hastaların \% 3-7'sinde, herhangi bir sebeple endoskopi yapılanların \% 1 , inde görüldüğü bildirilmiştir (Cameron, 1997). Adeno kanserin çoğunun Baret özofagus bölgesinden kaynaklandığı kabul edilir (Cameron, 1995). Barret özofaguslu hastalarda metaplastik epitelde adenokarsinom ve displazi gelişme riski vardır. Retrospektif ve prospektif çalışmalarda kesin olmamakla beraber Barret özofagusun maligniteye ilerlemesi her yıl yaklaş1k \% 1 olarak bildirilmiştir (Drewitz, 1997). Barret özofagus olarak bilinen hastalarda endoskopik takip ile displazi veya kanserin erken tespiti önemlidir. Endoskopinin takip aralığ1 güncellenen kanser insidansına göre değişiklik gösterebilir. Barret özofagus hastalarının halen birçoğu teşhis edilemediği için, endoskopik takipler adeno kanserden ölümleri azaltamamıştır. Son zamanlarda yapılan çalışmalarda adeno kanserli hastaların \% 10'undan azının daha önceden Barret özofagus olduğunu bildiği yayınlanmıştır (Menke Pluymers ve ark., 1992; Bytezer ve ark., 1999). Barret özofaguslu hastalarda GÖR semptomlarının olmaması tanıda gecikmeye neden olabilir. Barret özofagusuna bağlı adenokarsinom gelişme riski yılda \% 0,5 tir (Spechler, 2004).

Üst gastrointestinal sistem endoskopileri arasında Baret özofagus insidansı beyaz ırkta, siyah Amerikalılardan, İspanyollar ve yerli Amerikalılardan daha fazladır. Güney Afrika'da siyah ırkta, beyazlardan daha az Barret özofagus prevalansı vardır. Kaliforniya'daki Asyalılarda Barret özofagus prevalansı, aynı populasyondaki Asyalı olmayanlardan daha azdır. Güney Asya (Hindistan ve Pakistan) ve İran'da Barret özofagus prevalansı, Amerika'daki beyazlardan daha düşüktür. Singapurda Baret özofagusda Hintlilerde yüksek prevelans varken Çinlilerde prevelans düşüktür. Etnik farklardaki bu patern adeno kanserin insidansının coğrafi epidemiyolojik çalışmalarıyla oldukça benzerdir (Hongo ve ark. 2009).

\section{Akalazya}

Özofagusda peristaltik dalgaların yokluğu, alt özofagus sfinkter basıncında artma ve yutmada gevşeklik ile karakterizedir. Dilate özofagusda sıvı ve yiyecek artıkları birikir. Akalazyalı hastalarda skuamöz hücreli karsinom gelişme insidansı 3,4/1000 olup normale göre 16-33 kat daha fazladır (Sandler ve ark., 1995). Özofagus skuamöz hücreli kanserle bağlantısı daha çok görülmesine rağmen, Barret özofagus ve adenokanserle ilişkisi vaka sunumlarında değerlendirilmiştir (Fidaner ve ark., 2001; Pera ve ark., 2005). Aslında alt özofagus sfinkter basıncında artmanın Barret özofagus ve adenokanser etiyolojisinde yer alan GÖR'yu önleyeceği beklenir. Ancak akalazyalı erkeklerde skuamöz kanserler kadar adeno kanserin de arttığı bildirilmiştir. Akalazya tedavisi için yap1lan özofagomyotominin özofagus kanser riskine etkisi bulunmamıştır.

\section{Tylosis (Howel-Evans sendromu)}

Tylosis; avuç içleri ve ayak tabanlarının hiperkeratozu ile karakterli otozomal dominant geçiş gösteren bir hastalıktır. Bu hastalarda 4. dekatta \% 50, 6. dekatta ise \% 95 özofagus kanseri gelişir (Ellis ve ark., 1994; Risk ve ark., 1999).

\section{Human papilloma virüs (HPV)}

HPV'ün p53 proteini üzerinden etki ederek diğer etiyolojik ajanlarla sinerjik etki yaptığ kanserinde özellikle yüksek insidanslı bölgelerde \% 40-60 oranında HPV DNAsı tespit edilebilmektedir (Chen ve ark., 1994; Lam ve ark., 1997). HPV 6,11,16,18 ve 30 suşları şimdiye kadar tespit edilenler arasındadır.

\section{Özofagus darlıkları}

Özofagusun kronik darlıkları gıda stazına neden olarak nitrozaminlerin mukoza ile temasını uzatır. Kostik maddelere bağlı yanıklar sonucu oluşan striktürler, skuamöz hücreli karsinom riskini normal insanlara göre 20 kat artırırlar (Yu ve ark., 1988).

\section{Baş ve boyun bölgesinin skuamöz hücreli karsinoması}

Baş ve boyun bölgesinin skuamöz hücreli karsinoması olan hastalarda özofagus skuamöz hücreli karsinoma gelişme ihtimali yılda \% 3-7 oranında artmaktadır. Özofagus kanserli hastaların \% 1-2'sinde baş ve boyun kanseri saptanabilir (Erkal ve ark., 2001).

\section{Helicobacter pylori enfeksiyonu}

Helikobakter mide mukozasında atrofik gastrit yapar, mide asit salgısını azaltır ve özofagusun mide asiditesine maruz kalmasını azaltarak adenokarsinom oluşma riskini azaltır (Ye ve ark., 2004).

\section{KAYNAKLAR}

Alıcı, S., İzmirli, M., Doğan, E., 2006. Yüzüncü Yıl Üniversitesi Tıp Fakültesi Tıbbi Onkoloji Bilim Dalı’na başvuran kanser hastalarının epidemiyolojik değerlendirmesi. Türk Onkol. Derg. 21, 87-97.

Asaka, M., Kimura, T., Kudo, M., Takeda, H., Mitani, S., Miyazaki, T., Miki, K., Graham, D.Y., 1992. Relationship of Helicobacter pylori to serum pepsinogens in an asymptomatic Japanese population. Gastroenterology. 102, 760-766.

Basoglu, A., 2002. Özofagus kanseri ve cerrahi tedavisi. Özofagus hastalıklarının tıbbi ve cerrahi tedavisi. İstanbul: Bilmedya Grup. $229-253$.

Başoğlu, A., Çapan, A., Karaoğlanoğlu, N., Başoğlu, M., Demirel, M., Eroğlu, A., Varoğlu, E., 1998. Özofajektomi yapılan total vagotomili hastalarda piloromiyotominin mide boşalımına etkisi. GKDC. 6, 64-70. 
Bayram, İ., Recber, D., İbiloğlu, İ., Uğraş, S., 2005, Bir patoloji anabilim dalında kanser sıklığı ve dağılımı. Ege Tıp Dergisi. 44, $21-27$.

Blot, W.J., 1994. Esophageal cancer trends and risk factors. Semin. Oncol. 21, 403-410.

Blot, W.J., Devesa, S.S., Kneller, R.W., Fraumeni, J.F.Jr., 1991. Rising incidence of adenocarcinoma of the esophagus and gastric cardia. JAMA. $265,1287-1289$.

Blot, W.J., McLaughlin, J.K., 1999. The changing epidemiology of esophageal cancer. Semin. Oncol. 26, 2-8.

Bollschweiler, E., Wolfgarten, E., Gutschow, C., Holscher, A.H., 2001. Demographic variations in the rising incidence of esophageal adenocarcinoma in white males. Cancer. 92, 549-555.

Bosetti, C., Gallus, S., Garevello, W., Vecchia, C.L., 2006. Smoking cessation and the risk of oesophageal cancer; An overwiew of published studies. Oral Oncogoly. 10, 957-964.

Bozkurt, K., Bektaş, S.S., Doğru, N., 2011. Şırnak ilinin kanser istatistikleri. Türk Path. Derg. 27, 230-234.

Bytzer, P., Christensen, P.B., Damkier, P., Vinding, K., Seersholm, N., 1999. Adenocarcinoma of the esophagus and Barrett's esophagus: A population based study. Am. J. Gastroenterol. 94, 86-91.

Cameron, A.J., 1997. Epidemiology of columnar-lined esophagus and adenocarcinoma. Gastroenterol. Clin. N. 26, 487-494.

Cameron, A.J., Kamath, P.S., Carpenter, H.C., 1995. Barrett's esophagus: The prevalence of short and long segments in reflux patients. Gastroenterology. 108, 65 .

Chen, B., Yin, H., Dhurandhar, N., 1994. Detection of human papillomavirus DNA inesophageal squamous cell carcinomas by the polimerase chain reaction using general consensus primers. Hum. Pathol. 25, 920-923.

Corley, D.A., Buffler, P.A., 2001. Oesophageal and gastric cardia adenocarcinomas: Analysis of regional variation using the cancer incidence in five continents database. Int. J. Epidemiol. 30, 1415-1425.

Daly, J.M., Karnell, L.H., Menck, H.R., 1996. National cancer data base report on esophageal carcinoma. Cancer. 78, $1820-1828$.

Devesa, S.S., Blot, W.J., Fraumeni, J.F.Jr., 1998. Changing patterns in the incidence of esophageal and gastric carcinoma in the United States. Cancer. 83, 2049-2053.

Drewitz, D.J., Sampliner, R.E., Garewal, H.S., 1997. The incidence ofadenocarcinoma in Barrett's esophagus: A prospective study of 170 patients followed 4.8 years. Am. J. Gastroenterol. 92, 212-215.

Ellis, A., Field, J.K., Field, E.A., Friedman, P.S., Freyer, A., Howard, P., Leigh, I.M., Risk, J., Show, J.M., 1994, Tylosis associated with carcinoma of the oesophagus and oral leukoplakia in a large Liverpool family a review of six generations. Eur. J. Cancer B. Oral Oncol. 30 , 102-112.

Erkal, H.S., Mendenhall, W.M., Amdur, R.J., Villaret, D.B., Stringer, S.P., 2001. Synchronous and metachronous squamous cell carcinomas of the head and neck mucosal sites. J. Clin. Oncol. 19, 1358-1362.

Eser, S., Olcayto, E., Karakilinç, H., Karaoğlanoğlu, O., Yakut, C., Ozalan, S., Uçuncu, N., Anbarcioğlu, Z., Ergün, A., Akin, Ü., Yazici, M., Ozdemir, R., Ozgul, N., Tuncer, M., Sağlı Bakanlığı Kanserle Savaş Dairesi Başkanlığ1, Epidemiyoloji ve Koruma Şube Müdürlüğü, 20042006 yılları Türkiye kanser insidansı.

Garidou, A., Tzonou, A., Lipworth, L., Signorello, L.B., Kalapothaki, V., Trichopoulos, D., 1996. Life-style factors and medical conditions in relation to esophageal cancer by histologic type in a low-risk population. Int. J. Cancer. 68, 295-299.

Ghavamzadeh, A., Moussavi, A., Jahani, M., Rastegarpanah, M., Iravani, M., 2001. Esophageal cancer in Iran. Semin. Oncol. 28, 153-157.

Fernandes, M.L., Seow, A., Chan, Y.H., Ho, K.Y., 2006. Opposing trends in incidence of esophageal squamous cell carcinoma and adenocarcinoma in a multi-ethnic Asian country. Am. J. Gastroenterol. 101, 1430-1436.

Fidaner, C., Eser, S.Y., Parkin, D.M., 2001. Incidence in İzmir in 1993-1994: First results from İzmir cancer registry. Eur. J. Cancer. $37,83-92$.

Hongo, M., Nagasaki, Y., Shoji, T., 2009. Epidemiology of esophageal cancer: Orient to Occident. Effects of chronology, geography and ethnicity. J. Gastroen. Hepatol. 24, 729-735.

Hongo, M., Shoji, T., 2003. Epidemiology of reflux disease and CLE in EastAsia. J. Gastroenterol. 38, 25-30.

Ikeda, G., İsaji, S., Bas, B.C., Watanabe, M., Kawarada, Y., 1999. Prognostic significance of biologic factors in squamous cell carcinoma of the esophagus. Cancer. 86, 1396-1405.

Karaca, H., Berk, V., İnanç, M., Dikilitaş, M., Özkan, M., 2011. Erciyes Üniversitesi Tıp Fakültesi Tıbbi Onkoloji Bilim Dalı'na 2006-2009 yılları arasında başvuran kanser hastalarının epidemiyolojik değerlendirmesi. Sağlık Bil. Derg. 20, 1-8.

Kosem, M., Uğraş, S., Ozen, S., Bayram, İ., Ceran, F., Oral, H., Polat, S., 2001. Van gölü havzasında kanser sıklığı ve dağılımı. Çukurova Üniversitesi Tip Fakultesi Dergisi. 26, 30-36.

Kubo, A., Corley, D.A., 2004. Marked multi-ethnic variation of esophageal and gastric cardia carcinomas within the United States. Am. J. Gastroenterol. 99, 582-588.

Lam, K.Y., He, D., Ma, L., Zhang, D., Ngan, H.Y., Wan, T.S., Tsao, S., 1997. Presence of human papilloma virus in esophageal squamous cell carcinomas of Hong-Kong Chinese and its relationship with p53 gene mutation. Hum. Pathol. 28, 657-663.

Lewin, K.J., Riddell, R.H., Weinstein, V.W., 1992. Polyps and tumors.In: Gastrointestinal pathology and its clinical implications. Igaku-Shoin, NewYork. pp. 440-492.

Menke-Pluymers, M.B., Schoute, N.W., Mulder, A.H., Hop, W.C., van Blankenstein, M., Tilanus, H.W., 1992. Outcome of surgical treatment of adenocarcinoma in Barrett's esophagus. Gut. 33, 1454-1458.

Moutesano, R., Holistein, M., Bainaut, P., 1996. Genetic alterations in esophageal cancers and their relevance to etiology and pathogenesis: A review. Int. J. Cancer. 69, 225-235.

Oze, I., Matsuo, K., Ito, H., Wakai, K., Nagata, C., Mizoue, T., Tanaka, K., Tsuji, I., Tamakoshi, A., Sasazuki, S., Inoue, M., Tsugane, S., research group for the development and evaluation of cancer prevention strategies in Japan, 2012. Cigarette smoking and esophageal cancer risk: An evaluation based on a systematic review of epidemiologic evidence among the Japanese population. Jpn. J. Clin. Oncol. 42, 63-73.

Ökten, I., Güngör, A., 2003. Gögüs Cerrahisi. Cilt-II. Türk Gögüs Cerrahisi Derneği. Ankara, 1247-1308.

Parkin D.M., Bray F., Ferlay J., Pisani P., 2005. Global cancer statistics, 2002. CA Cancer J Clin, 55, 74-108.

Pera, M., Cameron, A.J., Trastek, V.F., Carpenter, H.A., Zinsmeister, A.R., 1993. Increasing incidence of adenocarcinoma of the esophagus and esophagogastric junction. Gastroenterology. 104, 510-513.

Pera, M., Manterola, C., Vidal, O., Grande, L., 2005. Epidemiology of esophageal adenocarcinoma. J. Surg. Oncol. 92, 151-159.

Pickens, A., Orringer, M.B., 2003. Geographical distribution and racial disparity in esophageal cancer. Ann. Thorac. Surg. 76, 1367-1369.

Risk, J.M., Mills, H.S., Gadre, J., Dunn, J.R., Evans, K.E., Hollstein, M., Field, J.K., 1999. The tylosis esophageal cancer (TOC) locus: More than just a familial cancer gene. Dis. Esophagus. 12, 173-176. 
Sandler, R.S., Nyren, O., Ekbom, A., Eisen, G.M., Yuen, J., Josefsson, S., 1995. The risk of esophageal cancer in patients with achalasia: A population-based study. JAMA. 274, 1359-1362.

Son J.I., Park H.J., Song K.S., Kim K.J., Lee C.Y., Lee S.I., Park I.S., 2001. A single center's 30 years experience of esophageal adeno carcinoma. Korean J intern Med; 16; 250-3

Spechler, S.J., 2004. Intestinal metaplasia at the gastroesophageal junction. Gastroenterology. 126, 567-575.

Spechler, S.J., Goyal, R.K., 1996. The columnar-lined esophagus, intestinal metaplasia, and Norman Barrett. Gastroenterology. 110, 614-621.

Uğraş, S., Dilek, H., Akman, E., 1996. Yüzüncü Yıl Üniversitesi Tıp Fakültesi Patoloji Anabilim Dalında tanı konan kanserlerin sıklı̆̆ı ve dağılımı. Van Tıp Dergisi. 3, 148-154.

Wu, A.H., Wan, P., Bernstein, L., 2001. A multiethnic population-based study of smoking, alcohol and body size and risk of adenocarcinoma of the stomach and esophagus. Cancer Cause. Control. 12, 721-732.

Ye, W., Held, M., Lagergren, J., Nyren, O., McLaughlin, J.K., Blot, W.J., 2004. Helicobacter pylori infection and gastric atrophy: Risk of adenocarcinoma and squamous-cell carcinoma of the esophagus and adenocarcinoma of the gastric cardia. J. Natl. Cancer I. 96, 388-396.

Yu, M.C., Garabrant, D.H., Peter, J.M., Mack, T.M., 1988. Tobacco, alcohol, diet, occupation, and carcinoma of the esophagus. Cancer Res. 48, 3843-3848. 